\title{
Hijab, sport and schooling in Finland - from principles to practice
}

Anna-Mari Almila

\begin{abstract}
This paper concerns the intersections between veiling, school and sport, focussing on both legislative elements and formal regulations, as well as the more micro-level practices of physical education teachers in school environments in Finland. Veiling is an extraordinarily politicised topic today, while also being an everyday dress practice engaged in by millions of women worldwide. Sport can be likewise politicised, and certainly is so in the case of veiling. Sometimes seen as resistance to patriarchal structures and cultural traditions, sometimes defended and justified using religious arguments, Muslim women's physical activities may be understood as a conflictual social field, especially when the women either choose to veil or prefer gender segregated venues for sport. Bringing together realms such as politics, legislation, education, garment design and religion, the debates surrounding female Muslim bodies are at the centre of ideas to do with citizenship and integration in Muslim-minority contexts. In Finland, both the national law and local regulations allow for a great deal of independence for teachers working with veiling students, at the same time as guaranteeing high protection of an individual's right to freedom of religion. Consequently, negotiation strategies between teachers and veiling students are central for the accommodation of religious dress practices. This is particularly so when teaching physical education, which has specific requirements for students' outfits from the point of view of safety and practicality. I discuss the complexities created by the fields of law, education, religion, politics and design when they come together in the case of hijabs, sport and physical education.
\end{abstract}

Keywords hijab, veiling, Muslim women, sport, physical education, Finland

\section{Introduction}

Veiling is an extraordinarily politicised topic today, while also being an everyday dress practice engaged in by millions of women worldwide. Despite the constantly increasing academic literature on the topic, political and media discourses remain often limited, and at worst outright incorrect and Islamophobic. In such conditions, the need at least to try to increase the variety of viewpoints in the debate is pressing. In this paper, I seek both to contribute to the global veiling literature in the form of a case study, as well as to increase understanding of the specific case of Finland in this regard. An under-researched location in terms of veiling, Finland employs in many ways very positive integration policies, but also the country is often a challenging environment for veiling Muslim girls and women to live and operate in. I consider here the intersections between veiling, school and sport, focussing on both legislative elements and formal regulations, as well as more micro-level practices, particularly of physical education teachers in school environments where Muslim pupils are present.

Sport, physical education and physical activity are considered as important strategies of socialisation of individuals in Europe. Many countries have national strategies with regard to physical education, both in school and throughout life (Dagkas and Benn 2006, EACEA 2013). Governments often consider sport and physical activity as crucial means of integrating people, 
especially non-European migrants (Pfister 2000). The European Charter of Women's Rights in Sport mentions Muslim women as one specific target group for which sports opportunities should be provided (Karlsson Minganti 2013). Sport can also be considered as a source of empowerment and potential for resistance. As McCrone (1988: 2) has argued, 'sport has considerable potential for social disruption, since it can operate as an important channel for underprivileged groups to challenge existing social arrangements and express hostility to and deviance from established norms'. This may be especially true for women. Turner (2008: 168) has argued that ' $[\mathrm{t}]$ he right of women to jog in the streets without interference from men is a political right, symbolic of their freedom to operate within the public domain'. Likewise for Muslim women, resistance to cultural and patriarchal norms can take the form of sporting activities, and Islamic doctrines may be used to justify female sport participation on religious grounds, such as stressing that Muhammad himself encouraged Muslims, including his own wives, to exercise. Obviously the success of such strategies depends on religious interpretations and socio-cultural factors (Dagkas et al 2011, Walseth and Fasting 2003, Jawad et al 2011, Almila 2018). Yet sport is not only a form of resistance, a fact worth remembering particularly in religious and ethnic minority contexts, where media channels often represent Muslim women's sports activities primarily as resistance to a presumed patriarchal and oppressive Islamic order (Toffoletti and Palmer 2017).

In this paper, I focus on the case of Finland, while recognising that the Finnish case cannot be understood in isolation, despite its peculiarities. After discussing veiling as a globalized phenomenon, I therefore briefly discuss the Finnish context more generally, and then specifically in terms of legislation, before looking into the complexities of hijabs, space and sport as well as veiling in the Finnish school system. I briefly consider practices engaged in by teachers of physical education in Finland, and potential problems which arise in relation to these. What emerges from my analysis is the implication that where powerful fields overlap the field of law and legislation (or the juridical field, as Bourdieu (1987) would have it), the field of education, the field of religion - this very overlapping itself, and the status that is given to each field in relation to the others, together create very specific conditions for the individuals who operate in the ensuing intersections. As we will see, in the Finish case, an ambiguous space is opened up whereby teachers sometimes struggle to know what to do about veiling Muslim girls in PE classes.

The Finnish Constitution and legislation allow for a very high level of protection for individual human rights, within which freedom of religion is included. Thereby, the Finnish case differs radically from the better-known and more debated European ones, such as France. Interestingly, I will show that such a setting as Finland creates certain noteworthy challenges for individuals operating within it, due to both the high level of constitutional protection and also the lack of concrete guidelines as regards how the hijab is to be treated in Finnish education in general, and physical education in particular. I will also indicate that, as has been the case in hijab controversies before, the field of clothing design may be utilised to support practices that ultimately would benefit all those concerned, pupils and teachers alike.

\section{Globalized veiling: religion, politics, fashion}


Veil, veiling, hijab, headscarf - whatever we call this dress phenomenon, ${ }^{1}$ it is both global and globalized today. This is so not only in the sense that the Muslim veil has spread to practically all parts of the world, but also because several related phenomena are interconnected across the globe. Women wearing the hijab express remarkably similar motivations for doing so in different parts of the world (Ahmed 2011). Indeed, across Europe the frames of anti-headscarf discourses have come to force categories upon veiling women, who are then made to 'defend' their dress choices (Bracke and Fadil 2012, Vakulenko 2012). The political discourses surrounding veiling are strikingly alike, and use the same discursive strategies, across Africa, Australasia, Europe and the Americas (Almila 2017, 2019). These discourses, involving both more general socio-political commentary, as well as more targeted debates - such as demands for legislation against the face-veil, or calls for banning burkini swimwear - also spread from one location to another, one country to another, and one continent to another, often in a very short timescale (Fitzpatrick 2009; Brems 2014).

Islam itself is also globalized today. A certain level of deterritorialization of the religion after World War II has created new tensions, particularly in terms of Muslim minorities around the world. In such diaspora settings, religious interpretations and practices tend to transform and take new forms altogether (Roy 2004). For example, some young members of the Finnish Somali community today are influenced by the globally influential Salafi Islamic thought, while some others have very secularised and moderate religious views. Traditionally, Somali religiosity has had certain Sufist elements, which still influence the views of some of the older generations. The older generation women also typically did not veil before the civil war, while a great majority of the younger generation has been required to veil since very young age (Almila 2018).

The apparent re-donning of the hijab by so-called second-generation immigrants in countries such as Germany, France and the UK, was considered by many in the host countries as a relapse into religiosity. Yet what we could call the 're-veiling' trend was part of a much wider phenomenon spreading across North Africa, the Middle East and beyond from the 1970s onwards. Although this trend was partly religiously-driven, it was also much influenced by a number of economic, socio-spatial and migration factors (Ahmed 2011). A combination of rural-urban migration, educational and employment opportunities and pressures for younger women, exposure to mixed-gender spaces in public transport, university campuses and workplaces, and the unaffordability of fashionable garments for many, made veiling an appealing alternative for women operating in environments that were unfamiliar to them (El Guindi 1999, MacLeod 1987, 1992). Islamic religious organisations sensed their opportunity in such developments and targeted their recruitment accordingly (Ahmed 2011).

This is also the context from which Muslim 'modest' fashion initially emerged. A form of antifashion initially created for the needs of women with economically limited means, who were spending long times in mixed-gender environments, by the 1990s a transnational system of fashion production, distribution and marketing had developed, which served the needs of urban middle-class women (Abaza 2007; Gökarıksel and Secor 2010, 2013; Jones 2007; Kelly 2010; Moors and Tarlo 2007). Today, forms of modest fashion constitute both a distinctive fashion system in its own right, as well as being part of long-established and globalized fashion systems more generally (Almila 2018).

\footnotetext{
${ }^{1}$ For an extensive discussion of these interrelated terms, see Almila 2017.
} 
From a European point of view, the hijab has been framed as a 'problem' since the late 1980s. In 1989 several legal cases took place whereby a girl's or a woman's right to cover her hair and her body were contested. The interesting element of these cases, and all those that followed, was that the vast majority concerned schools and other educational spaces (Batur 2012; Bowen 2007; Edmunds 2012; Lentin 2012; McGoldrick 2006; Scott 2007; Weber 2012). Intimately connected to ideas of citizenship and integration, school spaces seemed indeed a likely candidate for debates like these. Such debates have a remarkable tendency to focus on female bodies and female dress only: either the female covers too much and is considered oppressed, or she covers too little and is considered responsible for male reactions to her dress (Duits and van Zoonen 2006).

The veiling debates in Europe have been for a long time firmly framed within gender relations, whereby the 'European' gender system is declared superior to what is understood to be the 'Islamic' system of gender relations (Kiliç et al 2008, Rottmann and Marx Ferree 2008). In its most paradoxical form, such a framing has been used by radical right-wing political proponents in order to argue for the need of male protection of 'threatened' women, both 'white' and 'Muslim'. In such a usage, equality 'becomes an empty word used in the promotion of hegemonic power relations' (Lähdesmäki and Saresma 2014: 310).

\section{Finland - myths and reality}

For anyone who follows liberal UK media, it seems that Finland is the last remaining paradise on Earth. Happy, equal, uncorrupted, free, with a world-class schooling system - what is there not to like? Finland self-produces such mythologies too. An idealising narrative of people working together to build an egalitarian welfare-state-based country glosses over the legacy of the civil war in 1918, the years of fascist violence that followed, the discrimination against refugees from Karelia (which was annexed by Stalin's USSR) during and after World War II, the colonialist politics and policies in treatment of the indigenous Sámi people, high levels of domestic violence against women, deep-rooted gender inequality in terms of salary and career progress, strongly gender-segregated labour markets, as well as increasing poverty and a widening income and property gap between different social classes. Especially (but not only) for immigrants, Finland is not necessarily the land of unalloyed happiness and contentment.

There have been Muslims in Finland since the $19^{\text {th }}$ century, when the country was part of the Russian empire, and both Muslim soldiers and peddlers arrived in the territory. Many of the latter stayed, forming the earliest permanent Muslim community in Finland, the Tatar community. Their descendants are today a minority group among Finland's Muslims, with a population of around 1000 people. By the 1980s, the number of Muslims had doubled, to approximately 2000 individuals, when a small number of Muslims moved to the country, mostly due to pursuing education and getting married. The Somali civil war and the Yugoslavian war in the 1990s, coinciding with the collapse of the USSR and Finland's EU membership, changed the situation radically. Due to opening borders and refugee migrations, by the early 2000s there was estimated to be at least 40,000 Muslims in Finland (Martikainen 2008). The Finnish Institute for Migration estimated in 2015 that there were about 70,000 Muslims in Finland (Kantola 2015), while a US-based research institute estimated this number to be reached around the year 2020 (Forsberg 2015). The reason why it is impossible to give exact numbers is that the only statistics available concern members of religious communities, 
but by no means all Muslims are members of such entities (Martikainen 2008). Muslims probably count as less than $2 \%$ of the circa 5.5 million population of Finland today, a comparatively low percentage in the wider European context: in 2016, one estimate of Europe's Muslim population was around 5\% and growing (Pew Research Center 2017).

Racism and Islamophobia have been increasing in Finland for well over a decade, mirroring similar European trends. Particularly since the 2015 refugee 'crisis', attitudes against Muslims and Muslim immigration are increasingly openly expressed too. There have been waves of such developments previously, such as after the 2001 New York terror attacks and other wellpublicised incidents (Allen and Nielsen 2002, Keskinen 2009, Human Rights First 2007). In the Finnish racialised social hierarchy, those with Somali, Afghan, Iranian, Iraqi or Turkish backgrounds are most vulnerable to discrimination (Puuronen 2011). Finnish Somalis have reported very high levels of racial harassment and discrimination, significantly high even in the wider European context (Tuori 2012). As a sign that such harassment is not only racially directed, but often targets especially Muslims irrespective of their ethnicity, Finnish converts to Islam, especially veiling women, have also reported instances of harassment and discrimination (Almila 2018).

A part of such developments has been attributed to the rise in Finnish politics of the populist radical right Finns Party [Perussuomalaiset]. Especially since the current head of the party took over the leadership, openly racist expressions and attitudes have been tolerated and even encouraged within the party. This is hardly surprising, given that the party head, Jussi HallaAho, has been convicted of disturbing religious worship [uskonrauhan rikkominen] as well as of incitement to hatred against particular groups of people or communities [kiihottaminen kansanryhmaa vastaan]. His anti-human rights writings online have inspired, among others, the Norwegian right-wing terrorist Anders Breivik.

Many authors have noted that the turning point of political and media rhetoric was the 2008 local elections, when the Finns Party first claimed some victories (Puuronen 2011, Keskinen et al. 2009, Keskinen 2009, Rastas 2009, Raittila 2009). The party's success in the 2011 parliamentary elections was attributed partly to the party's 'immigration criticism' (Borg 2012), at a time when anti-immigrant attitudes among the Finnish population had been increasing (Haavisto and Kiljunen 2011). It can be argued that the Finns Party filled a demand in a political market where, up until this time, anti-immigrant themes were rarely explicitly engaged with by the mainstream parties. Shortly before the rise of the Finns Party, Kestilä (2006) argued that the lack of radical right success in Finland was due rather to supply-side factors than to a lack of anti-immigrant attitudes among Finns. Finnish politics, attitudes and discourses clearly follow certain wider European trends, such as the apparent polarization of 'the West' and Islam, the increasing popularity of right-wing political populism, and the construction of Muslim women as both threat and victims of Muslim men (Bartlett et al 2011).

\section{On Finnish legislation}

The Finnish Constitution declares the equality of individuals, and guarantees the freedom of expressing, declaring and practising religion. Such constitutional rights, however, are also declared by the constitutions of countries where certain religious practices are banned in public institutions and public places, such as face-veiling in public and wearing headscarves in public 
schools in France (Fornerod 2017). It is therefore important to understand how individuals' rights to religious freedom are related to other legal rights and to restrictions of these. For example, the European Court of Human Rights (ECtHR) has repeatedly allowed a so-called 'wide margin of appreciation' to countries such as France and Turkey, which means that the 'secular' ${ }^{2}$ character of a State has been considered more significant a factor than an individual's right to religious freedom, in situations where these two are understood to be in conflict (Westerfield 2006).

Two legislative elements are important when evaluating the Muslim community's position in Finland: interpretations of both the Constitution and laws, in terms of freedom of religion; and legislation against discrimination. The Finnish legislation on freedom of religion goes back to 1922, and it resulted to the registration of the first Muslim community in 1925 (Martikainen 2008). The law guarantees the right to organise and register as a religious community, and an individual's right to be a member, or not be a member, of a religious community or church. In terms of discrimination, Finnish legislation makes a distinction between the principle of equality [tasa-arvo], which deals with gender equality, and the principle of parity [yhdenvertaisuus], which covers every other type of ground for discrimination, such as ethnicity and religion. The first parity legislation dates back only to 2004, when it was formulated in response to the European Union's demands concerning member states' antidiscrimination legislation (Aaltonen et al 2009, see also Lewis 2013).

Forms of legislation are not equally powerful, however. When making a complaint about discrimination, a person may need to consider which ground of discrimination is most likely to lead to positive results. When the law against other than gender-induced discrimination [yhdenvertaisuuslaki] was first formulated, it was significantly weaker than legislation against gender discrimination [tasa-arvolaki] (Aaltonen et al 2009). This led to a new Parity Law in 2014. That law states that all representatives of the State or municipalities, all organisers of education, as well as public and private employers, have the duty to promote parity. This is usually interpreted not only as forbidding direct and indirect discrimination against individuals or groups, but also as enabling positive discrimination when deemed necessary and justified. The new law also centralised the handling of complaints, which had previously been handled only at the municipal level, thus aiming for consistency in judgements and recommendations. One major way of enforcing the legislation is for officials such as the Ombudsperson for Parity [vähemmistövaltuutettu] to give recommendations and statements, as well as judgements on individual cases, which are expected to be followed and can be enforced through sanctions, but which do not hold the legal status of court rulings.

Finland has ratified human rights treaties of the United Nations, as well as the European Convention of Human Rights (ECHR). Once ratified in the Finnish legal system, such treaties come to define the lowest level of human rights protection each individual is entitled to: 'within the Finnish legal system, these international obligations themselves also have the status of the law incorporating them' (Venice Commission 2008: 20). What is significant here is both that these treaties are considered binding by the Finnish legislative system, and also that they define the minimum protection of individual rights. This principle of 'human rights friendly' interpretation of law [perusoikeusmyönteinen tulkinta] means that the international treaty

\footnotetext{
${ }^{2}$ While some parts of the Finnish public sphere are secularised, Finland is not a secular country when it comes to how the State is organised. The Evangelical Lutheran Church of Finland and the Finnish Orthodox Church enjoy special rights, and the former especially has many ties with the State.
} 
which guarantees the highest protection of individual rights becomes the minimum level of protection in the national context. So the Finnish interpretation of international human rights treaties differs from, for example, the French interpretation, where in the latter laïcité is a stronger principle than freedom of individual religious expression in the public sphere.

The constitution guarantees not only religious freedom but also the right to wear the clothes of one's choice (EOAK 1455/2007, see also Almila 2018). ${ }^{3}$ For example, the Highest Court has considered the traditional dress of Roma women as an elementary part of Roma culture and thereby protected by the Constitution (Hokkanen 2014). There are no specific regulations on veiling in Finland, but nor are there many explicit statements allowing it. In one exception, wearing a scarf in passport photographs is specifically allowed in Finland, as long as the scarf does not hinder identification (EOAK 2079/2002). Face-veiling, too, enjoys a high level of legal protection in Finland. When the government sought to ban face-covering during political demonstrations in 2004 (for which religious face-covering was to be one exception) (HE $81 / 2004),{ }^{4}$ such a general ban was found unconstitutional, for individuals have the right to participate in demonstrations anonymously. ${ }^{5}$ The law that came into effect banned facecovering during a demonstration only if there is clear intention to harm other people or property (LaVM 8/2004). ${ }^{6}$

The Finnish Sports Act of 2015 [Liikuntalaki] states that local authorities must promote opportunities for exercise, and thus promote health, for all citizens. The purpose of the law is 'to promote physical exercise, competitive and top-level sport, as well as related citizens' activities, to promote well-being of the population and health, and support the growth and development of children and youth' (390/2015). The law states that in terms of sport and exercise facilities, individuals should be treated equally, irrespective of their gender or cultural backgrounds. As we will see in the next section, the question for interpretation that arises here is what 'equal treatment' is taken to mean, and how equal opportunities for all are promoted.

\section{Veiling, sport and access to spaces}

Muslim women have been participating in international competitive sports at least since 1936, when Turkey sent its first female athletes to the Olympic games (Amara 2012). However, the last two decades have seen some well-publicised battles over inclusion and dress in sports. In 2007, FIFA - the governing body of world football - banned the hijab in competitions. This decision was partly revised in 2010, allowing the covering of hair but not the neck. However, after extensive media coverage in 2011 of the banning of Iran's female football team from

\footnotetext{
${ }^{3}$ EOAK refers to Eduskunnan oikeusasiamiehen kannanotto, Statement by the Parliamentary Ombudsman. Such statements are given in response to complaints made by citizens. In the statement referred to here, it was considered unconstitutional to stop inmates from wearing their own clothes in prisons. The complaint was made by a female inmate in the Hämeenlinna prison (southern Finland), who considered the exception that allowed Muslim women to wear their own scarves, when other inmates were banned from wearing their own garments, as discriminatory. The Parliamentary Ombudsman agreed.

${ }^{4} \mathrm{HE}$ refers to Hallituksen esitys, a Government Proposal [for a new law].

${ }^{5}$ Interestingly, in Hamburg, Germany, a local school's attempt to ban a student from wearing the face-veil was recently considered to be against regional legislation, which guarantees freedom of religion to a very high degree (MTV 2020). This is a different type of case from Finland, however, as there may not be constitutional reasons why a law enabling such a ban could not be introduced.

${ }^{6}$ LaVM refers to Lakivaliokunnan mietintö, Report of the Committee on Legal Affairs.
} 
playing unless they removed their scarves, the ban was lifted in 2012. Even the UN participated in the debate, making a pro-scarf statement (Joseph 2013).

Interestingly, the availability of safe and functional sport scarves was a key factor in the decision, since the ban was justified on health and safety grounds, as well as on the grounds of religious neutrality (Ayub 2011). Dutch designer Cindy van den Breman had introduced a sports scarf that was considered to fulfil the requirements for competitive football (Joseph 2013). Along similar lines, the sports scarf designed by the Canadian Elahm Seyed Javad was integral to the decision of the International Taekwon-Do Federation in allowing the hijab in competitions. There are also other competition fora in which athletes who veil can participate, such as the Islamic Games held in Iran, which are gender segregated (Ahmad 2011). But for those who want to compete in gender-mixed sporting platforms, decisions either to allow the hijab, or at least not to ban it (Ayub 2011), have central importance.

A focus in this regard on the more spectacular and well-publicised cases may obscure the more hidden spaces of physical activity (Benn et al 2011). It is the case that often Muslim minority girls meet with various barriers to participation in sports and physical education. Some conservative clerics are opposed to female sport participation (Jawad et al 2011). Family influence, which is typically extensive, may also hinder participation. Discrimination against hijab-wearers, as well as mixed-gender spaces deemed unsuitable for physical exercise without the hijab, add another layer of potential barriers to participation. In this context, becoming a sports educator may be particularly challenging for a veiling Muslim woman (Dagkas et al 2011). A further problem for such women may be how sport-related spaces such as dressing rooms and showers are arranged. Because displaying nudity in front of other women is deemed inappropriate by many Muslims, women may need to develop various strategies of ensuring their privacy in gender-segregated settings that provide for limited individual privacy (Shavit and Wiesenbach 2012, Karlsson Minganti 2013, Almila 2018).

Another more spectacular sports and veiling issue during recent years has been the case of the 'burkini' - 'modest' swimwear worn by some Muslim (and orthodox Jewish) women. This is an interesting case, as it concerns 'ordinary' Muslim women, and much less so competitive athletes. ${ }^{7}$ Already well before the attempts to ban the burkini in various locations in France during the summer of 2016 - a ban which French courts found unconstitutional (Al Jazeera 2016) - the burkini was a target of often negative international media coverage. Media stories, initially triggered by the well-publicised launch of designer Aheda Zanetti's Burqini ${ }^{\mathrm{TM}}$ in Australia, circulated across different national media (Fitzpatrick 2009). The garment was designed to solve problems faced by some Muslim women: gender-segregated swimming hours were banned in certain swimming pools, and swimming while wearing covering garments which were not designed to be swimwear turned out to be either socially challenging or forbidden altogether. Zanetti's co-operation with the organisation Surf Lifesaving Australia

\footnotetext{
${ }^{7}$ In fact, it might be impossible for a Muslim who observes Islamic dress codes, whether woman or man, to participate in swimming competitions in Finland, as '[m]en's swimwear must not reach above the navel or below the knee [and w]omen's swimwear must not cover the whole back or the shoulders, or reach below the knee'. Neither of these demands fully fits with Islamic requirements of modesty, although men may be able to find an outfit that would suit both the competition rules and Islamic requirements, the latter usually considered to demand the covering of the area between the navel and knees. For women this would be practically impossible.

https://www.aquanetti.fi/ohjeetkisapuvunvalintaan
} 
resulted in 2009 in the first veiled lifesaver, who graduated while wearing a Burqini ${ }^{\mathrm{TM}}$. International media coverage and massive global sales followed (Khamis 2010).

There have been debates both about the burkini and about gender-segregated swimming hours in numerous countries and locations within them (Shavit and Wiesenbach 2012, Karlsson Minganti 2013, Stadt Alfeld 310/XVII, Almila 2018, Lenneis and Agergaard 2018). The discursive elements evoked are fairly similar across different places, citing gender equality and discrimination, integration concerns, and even fears of 'Islamization' (Shavit and Wiesenbach 2012). During the 2008 communal elections in Finland - which are widely considered as the turning point in anti-Muslim and anti-immigrant sentiment - a National Coalition party [Kansallinen Kokoomus] candidate wrote about Muslim women's swimming hours in her campaign blog. At that time, three swimming halls, in the cities of Helsinki, Vantaa and Turku (south and south-west Finland), each had a weekly two-hour session dedicated specifically for Muslim women, who, due to religious reasons, could not swim with men (EOAM 208/2008). ${ }^{8}$ These were called alternatively 'Muslim women's', 'immigrant women's', or 'women's' swimming hours.

The blog post brought these arrangements to public attention, and this provoked a great deal of controversy and a debate about how publicly-funded exercise places are to be used. The short weekly sessions when the swimming hall was closed to men can hardly have had much practical importance. In fact, the management of one of the swimming halls in question stated explicitly that they chose the quietest hours for these gender-segregated swimming sessions, and they pointed out that there were several public swimming halls in the area that were available for men during these hours (EOAM 208/2008). The debate can therefore be seen as a clash over perceptions of public and publicly-funded spaces. The arguments against gendersegregated swimming were made in terms of equality, with positive discrimination being considered unfair. There were also arguments about how taxes should or should not be used, including claims and assumptions that migrant women, and migrants in general, would not pay taxes (similar claims have been made elsewhere in Europe, too - Shavit and Wiesenbach 2012). The Parliamentary Ombudsperson declared that segregated swimming hours can be considered a form of positive discrimination that supports integration. ${ }^{9}$ Therefore they are a legitimate practice that cannot be banned (EOAM 208/2008).

Different understandings as to what encourages and discourages integration are interesting in this regard. While Finland considers positive discrimination as a force for integration and therefore acceptable for the reasons of equal treatment, Switzerland, for example, considers such special treatment to be against both equal treatment and integration (Amara 2012, Dabbagh 2017). Similarly, in Denmark, the city of Aarhus decided to ban the popular womenonly swimming sessions in February 2017, as the sessions were considered a 'disservice' to integration initiatives by the city council (Lenneis and Agergaard 2018). Yet at the same time, sport is considered a central integration strategy in Denmark (Pfister 2011). Conversely, in Australia, while women-only swimming is considered to be against anti-discrimination laws,

\footnotetext{
${ }^{8}$ EOAM refers to Eduskunnan oikeusasiamiehen mietintö, Report of the Parliamentary Ombudsman.

${ }^{9}$ Another physical activity considered central to integration in Finland is cycling (Paavola 2016). Cycling is not only a physical activity, but also a public act that increases the mobility of an individual, thus providing her with new spatial possibilities. Cycling has historically played a role in women's liberation. It can be considered the single most significant activity to provide women with means of access to public spaces, spatial mobility and spatial liberties (McCrone 1988, on Muslim women cycling in Finland, see Almila 2018).
} 
an exemption can be granted by the State to carry on such activities when they are considered to enhance integration and cross-cultural contacts (Australian Leisure Management 2012). In the USA, in June 2016, a complaint was made against a swimming pool in Brooklyn, stating that women-only swimming hours in an area inhabited by a large number of Orthodox Jewish people amounted to exclusion from a public facility based upon gender, as well as contradicting the principle of separation of church(es) and State. The pool continued women-only sessions despite the complaint, but disagreement as to whether such a practice is beneficial (for nonreligious as well as religious women) or anti-secular in nature, is ongoing (Melton 2016).

In Finland, different towns take different stances in terms of the burkini. In the Greater Helsinki area, it is allowed in Helsinki and Espoo, but it was banned in Vantaa in early 2016. In 2019, the town of Kotka (south-east Finland) allowed burkini swimwear for school groups in its public swimming halls (as well as the wearing of a swimsuit in saunas for transgender people) (Tillaeus 2019). Both stances are often justified by referring to 'equal treatment', but Vantaa's decision to ban burkinis was allegedly due to hygiene concerns: other patrons had complained that burkini-wearers do not shower (likely for the modesty reasons indicated above) before going into the pool. However, as the burkini is still allowed during women-only swimming hours (Savolainen 2016), the stance seems somewhat contradictory. Some contra-burkini arguments in public debates try to frame the swimwear in question as being against 'Finnish equality' (Jokiniemi 2016). The rather common ban on male shorts in swimming halls is also defined as discriminatory by critics of burkinis, although shorts are usually banned for not being made of swimming-suit fabric.

The usual rules where the burkini is allowed in swimming pools in Finland are as follows. The burkini must be made of swimming-suit fabric, and be of a 'tight' cut, as loose fabric is considered a safety risk. Furthermore, no underwear must be worn under the swimwear, and the burkini must be put on only after showering. Swimming halls in Espoo also offer burkinis to rent for both adults and children (Savolainen 2016). However, the differences between different swimming halls, sometimes also within the same town and area, can cause confusion and discomfort. The national Students' Sports Federation has expressed their concern about practices they consider discriminatory against specific minorities (Jokiniemi 2016). The debate is very much ongoing, and it causes difficulties for accessing spaces for exercise, particularly for those Muslim women who are unable to attend the rare women-only swimming sessions.

Especially in cases where wearing the burkini is not allowed, women-only swimming hours may be the only possibility for veiling Muslim women to go swimming. Moreover, there are women who would consider swimming in mixed-gender spaces as inappropriate, even when they were wearing the burkini (Karlsson Minganti 2013). Importantly, many municipalities and cities in Finland today regard access to public sports venues as an equality question. The Finnish Swimming Teaching and Lifesaving Federation sees this also as a safety issue. In a country where water is practically everywhere, swimming is a crucial skill of survival. The Federation is involved in developing 'multicultural swimming teaching', in collaboration with a multicultural school in town of Raisio in south-western Finland (Tillaeus 2019).

\section{Veiling in Finnish schools}


The following is an official document of suggested actions in 2010 for the Education and Culture Board of the town of Raasepori, in south-western Finland. The motion was passed, but there were calls for more specific guidance from the national level education officials.

In western Uusimaa area [south-west Finland] there has been so-called preparatory education for immigrant children since the 1990s. [...]

It has been the principle of the school that the pupils do not wear headgear in school, [and] do not wear a headscarf or religious symbols during the school hours. This has until now caused no great problems, but for example girls who according to Islamic tradition have worn a headscarf, after having had the rules explained to them, have taken it off for the duration of lessons, and the parents have accepted this.

In March new refugees arrived in Raasepori: Iraqis from Syria, and now it happened that one family considered this rule unacceptable. This led to the parents not allowing their 13year-old daughter to participate in education in school. The same will be true for their sevenyear-old daughter who has now started to wear the scarf. Consequently, one of the parents, usually the father, have not participated in their own [integration] training course but have stayed at home with the children instead.

In a meeting with representatives of the Islamic Union it was noted that Finland has no law or regulation banning scarves - nor allowing them either. The same is true of the guidelines and rules from the National Board of Education: there is no official statement about the matter - the only guideline is that such religious values that have central importance to the individuals involved must be respected.

Suggested action:

The Education and Culture Board decides that scarves and other religious symbols are not banned in the town's schools. (Mattson 2010, my translation, first emphasis in original, other emphases mine)

As this document points out, in Finland there are no general laws or regulations in regard to the hijab. Consequently, the practices of banning - of which this is the only example I have come to be aware of during extensive research on such matters - or allowing it are the responsibility of local officials. In accommodating and governing a social and religious minority, several kinds of policies may be used. Phillips (2005) makes a distinction between extension, exception and autonomy policies. The latter, which means partial legislative selfgovernance, usually in cases of property and family law, is not practised in Finland in respect to Muslims. Both extension - whereby minority groups achieve similar or the same rights as the majority, such as the freedom of religion law allows - and exception - where a general rule is considered discriminatory in the case of a particular minority, and thus an exception is made for them - are practised on the ground in various ways. The document above is an example of an exception being made pragmatically, with local officials improvising within the limits set for them by the very general guidelines. The rule followed in the Raasepori school initially equated headscarves with any other kind of (presumably non-religious) headgear. In the first instance, the policy had been to expect the migrants to adapt. Only when one family refused to conform were changes deemed to be necessary and implemented. 
In the document cited above, the 'headscarf' is first likened to a religious symbol based on religious tradition. These definitions are extremely significant. Defining the headscarf as a symbol likens it to other symbols such as Christian crosses, and does not acknowledge that veiling women themselves often consider the scarf not as a symbol but a mandatory religious practice. Also, considering the headscarf as a religious tradition rather than a doctrinal order or imperative, further frames it as a practice that is not necessarily central to the religion itself. Later on in the document, central religious values are mentioned. So the question becomes whether the hijab is, or represents, a central enough religious value to be respected. It is to be noted that the document does not indicate whether the community representatives of the Muslims in question considered the hijab central to Islam or Islamic doctrine. It is also true that it may well be difficult or impossible to get a clear opinion on this topic from a truly representative group of Muslims given the number of doctrinal interpretations available in this regard. As Roy (2004) has argued, often the only Islamic scholars willing to give clear-cut, simple and definitive answers to doctrinal questions are religious and political radicals.

In the suggested action advocated by the officials, the nature of the exception made in this case becomes clear: while religious symbols, and thus headscarves, are no longer banned, nothing more is said about headgears in general - so presumably they continue to be banned. Although allowing all religious symbols to be present in school indicates a desire to uphold principles of equal treatment of individuals, the definition of the hijab as a religious symbol separates it from other headgears and allows it a special status. ${ }^{10}$

As this example highlights, the school policies, in accommodating various forms of hijab, are based more on negotiations between local officials and students and their families than on any general regulation, be it municipality- or nation-wide. So, for example, at least two vocational schools in Finland state in their dress guidance that face-veils are banned during school days. ${ }^{11}$ But I have been told by a Somali woman whom I interviewed for an earlier research project (Almila 2018) that when she at the age of 15 decided to wear the niqab (face-veil) for school (because she thought it was 'cool'), she was not forbidden to wear it, but her mother was invited to the school to discuss the matter. The school management consented to the girl's dress choice, but she personally faced severe bullying on the part of the other pupils in the school. Nevertheless, she continued to wear the face-veil for several years, until finally taking it off for pragmatic reasons related to her adult workplace.

In 2004, some years before the case described above, a brief commentary concerning religious headgears was given as a statement by the Education Minister of the time. This came as a response to the Christian Democrat MP Päivi Räsänen's enquiry regarding the newly introduced French law to ban headscarves in public schools: 'What is the stance of the Government of Finland to the European headscarf debates?'

In Finland the question concerning using religious symbols in school has not been particularly pronounced. According to the Constitution and legislation concerning education, a student's convictions must be respected, and religious freedom, which is declared as a human right, involves the possibility to practice one's religion. [...]

\footnotetext{
${ }^{10}$ In fact, political garments and symbols have been allowed in Finnish schools since 1968, after they had been banned due to the spread of fascist uniforms in 1934 (see Almila 2020). In light of this, the banning of religious symbols in a school seems rather odd.

${ }^{11}$ https://www.sdo.fi/hakijalle/pukeutumisohje/; https://opiskelija.keuda.fi/assets/Uploads/Pukeutumisohje.pdf
} 
The laws regarding education require proper behaviour from students. Proper behaviour is considered to include a requirement for proper dress. For example, wearing a scarf is generally accepted. The regulations concerning a safe learning environment and workplace safety allow for interference when a certain dress style could [...] cause evident danger to the student or others. Students' dress should also be such that the student can be recognised and their performance can be evaluated.

$[\ldots]$

In Helsinki $23^{\text {rd }}$ February 2004

Education Minister Tuula Haatainen (KK 37/2004 vp, my translation, my emphases) ${ }^{12}$

In light of this statement, it is understandable that there may be a sense of limited guidance for local officials in questions such as these. For example, some could argue that banning a faceveil would thereby be legitimate, as it may hinder recognising the student. Yet, others might argue that visibility of the face is actually not necessary for recognising an individual, and therefore banning the face-veil has no legal grounds. To my knowledge, the face-veil bans of the schools mentioned above have not been challenged, and certainly not in legal terms. The outcome of such a challenge would be by no means clear-cut or obvious.

\section{Teaching physical education}

The national school curriculum set by the Board of Education [Opetushallitus] in 2016 states that the purpose of physical education in schools is to 'promote parity, equality and communality, as well as to support the diversity of cultures' (Opetushallitus 2014: 433). The curriculum outlines key learning outcomes, which include swimming and water self-rescue skills. But considering all the complications around veiling, sport and schools, it can be expected that physical education classes are venues where controversies around female dress may well emerge. As pointed out above, these are issues that are typically solved in negotiations between teachers, students and students' families.

Previous research has shown that teachers are usually willing to reach compromises, such as veiling girls not joining swimming classes but taking other forms of exercise (such as walking) instead, or swimming during women-only sessions in local swimming halls. On the other hand, such arrangements raise the issue of safety and responsibility, when the students exercise unsupervised by the teacher (Vastamäki 2004). Yet it has been found that participating in gender-segregated swimming functions as a 'gateway' to swimming outside of these sessions (Fagerlund and Maijala 2011), which from the point of view of the State can be considered a highly successful outcome for integration strategies.

Despite the willingness to accommodate students, dress for physical education classes remains controversial in terms of what is considered 'equal treatment' in terms of appropriate dress for the purposes of participating in a class. For example, (long) skirts may be considered a safety hazard. It may also not be clear to a teacher how many interpretations of Islamic doctrines there

\footnotetext{
${ }^{12} \mathrm{KK}$ refers to kirjallinen kysymys, a Written Question [to the Government].
} 
are, and thereby why students from different ethnic backgrounds follow different rules as regards dress, both in mixed-gender and gender-segregated spaces.

Fagerlund and Maijala (2011) also point out that to assume that Muslim girls are a special case may make them such. Well-meaning initiatives by school teachers and other organisers of sporting activities for youths may inadvertently encourage non-Muslim adult supervisors to think of Muslim students in a 'victim-frame', ignoring the fact that often the students themselves express a desire to respect parental wishes as to appropriate dress, even if those would differ from their own personal views. Therefore, they argue, especially in terms of creating gender-segregated spaces, it should be evaluated on a case-to-case basis whether such an environment is needed, or whether it would only serve further social marginalisation.

For this part of the paper, in order to update and augment the knowledge gained by previous (very limited) research on this topic, I conducted a short online survey with physical education teachers of secondary and upper secondary schools (serving 13-18+ year-old students) in the Greater Helsinki area, which is formed of the cities of Helsinki, Vantaa, Espoo and Kauniainen. I received 17 responses ( 5 from Helsinki, 6 from Espoo, 7 from Vantaa). Obviously this is a limited sample. But within the limitations of the data, the responses draw a mostly positive picture of the current situation, in the sense that almost half of the respondents reported no problems during the PE classes they teach. The majority also indicated that they saw no need for guidance on the part of the school management or from other institutions. They generally felt perfectly capable of solving potential issues themselves.

Teaching in the schools I got responses from happens in either mixed groups, or both mixed and separate groups, or gender-segregated groups only. All these obviously create different kinds of challenges for veiling students. For example, one of the teachers showed particular concern and care for the students in their girls-only group when describing a problem situation. When a boy suddenly entered a venue where a Muslim girl was exercising without her scarf, the teacher told that she 'has gone in front [of the girl] to stand as a screen'. This is obviously less of a problem in mixed-gender groups where girls would veil, or for those girls who veil regardless of the group.

The most regular veiling-related issues concerned safety during classes on the one hand, and swimming on the other. Overly loose scarves were mentioned as problematic by two teachers, but this was considered a minor issue in comparison to long skirts. For issues to do with swimming, several solutions were mentioned. Students may go swimming separately, skip swimming altogether and replace it with another sport (which seems to be allowed by some, despite the national curriculum mentioning swimming as a key skill to be improved during the secondary school grades 7-9, and one of the evaluation and marking criteria for physical education - Opetushallitus 2014: 433-6), or they might borrow a burkini (which is possible in Espoo, where to-rent garments are available) when required to do so by their family. One of the respondents mentioned concerns regarding the physical activity of veiling girls in general: 'Many avoid sweating and are physically passive in physical education classes. Almost no scarf-wearing Muslims girl is physically active'.

In regard to guidance about students' sportswear, one of the respondents declared that 'there is a guideline regarding sportswear, but wearing religious headgear trumps it'. What the teacher meant here was that the principle of religious freedom, including the right to wear religious clothes, over-rides any other considerations, including guidance as to what is appropriate to 
wear in PE classes. About a third of respondents wished there was more guidance as regards accommodating the hijab in sports classes. One concern was how adequate (or inadequate) clothing should affect evaluation and grading of students. Another concern had to do with safety, especially as regards long hems on garments:

I'd wish to get a clear line [of guiding principles], so that a student couldn't always appeal to religion [to get their way in terms of their dress]. From the point of view of exercise, long skirts are a bigger problem [than scarves], [and they] clearly limit physical activity in various situations. There should be clear information as to what I can comment upon, and take into account in grading, if a student is inadequately dressed for a PE class.

Among those respondents who wished for clearer rules were both those who had experienced some issues with veiling, as well as those who reported that there had been no problems.

The State could give general level safety guidelines. Usually things can be solved using common sense, but sometimes one meets situations where stricter guidance/ regulation/ legislation would be a useful support [for my teaching practice].

What is worth stressing here is that in a context where individual teachers have significant power to formulate and negotiate their practices as regards veiling regulations, there is always also a certain potential for vulnerability, if teachers misjudge situations or even abuse their position. As stated by Ayub (2011), what is not explicitly allowed, may come to be banned. Therefore, understanding teachers' practices in this regard is crucial, especially in a context such as Finland, where State and local regulations allow for great deal of independence of judgment for those who operate with veiling students. As Fagerlund and Maijala (2011) point out, it is not enough to say you are open to everyone. It is one's actions which prove such statements true or false. It is also clear that the teachers are aware that they carry a responsibility in this regard, and many would prefer clearer guidelines that would make their work easier and more predictable, as well as ensure equal treatment of all students. There is also the question of a teacher's right to guidance and support, from local and State-level authorities, in terms of how to treat students with different religious and cultural practices.

What emerges from these considerations is a sense of a certain kind of a vacuum created by the Constitution and legislation that protect individual rights to an extremely high degree. Such conditions allow for students and parents to claim rights in the name of religion, and they may make teachers reluctant to react when such rights are demanded, even when such exceptions may seriously limit a student's participation in physical education. Yet there are solutions, most importantly 'modest' sportswear. A combination of (national) guidelines defining what appropriate physical education dress would mean as regards veiling students, as well as financial and/or other forms of support for families to access such sportswear (such as a possibility of borrowing suitable garments from the school), would protect both the students' right to physical education and the teachers providing such education. The field of design can be drawn upon to help both students and teachers, potentially making negotiations between the two groups easier and less unpredictable. Furthermore, I suggest that an elementary level of understanding of veiling phenomena is a skill highly relevant for PE teachers, and it should be a core part of teacher training, if the goals of supporting and promoting diversity, parity and equality are to be truly realised. 


\section{Conclusion}

I have shown in this paper some elements of the extreme complexity that veiling, education and sports phenomena may be embedded in within a specific national context. Although the politics of veiling and veiling practices are highly globalized, they are also very much local and operate at a pragmatic level in people's everyday lives. The juridical field holds a key position in the Finnish case, for it creates a situation whereby individuals are made to negotiate veiling-related practices with highly binding legal principles but little pragmatic guidance. It must also be noted that as regards the right to choose one's clothes, the situation is resistant to changes in political mood, as this right is considered constitutional, and is not ordained by other legislation. ${ }^{13}$

When several powerful social fields overlap, the pragmatic consequences can be expected to be potentially conflictual. In my reading of the case, primacy have been given to the fields that necessarily frame teaching practices, that is, law and education. These are shown to be very independent of other fields, such as religion, which is understood to matter only as regards the legislation on freedom of religion and individual human rights. Such a situation allows for individuals to request specific rights, but it gives limited consideration as to the benefits or otherwise of such rights. In an ideal situation, granting special rights may enhance integration and belonging. In a less positive case, insecurity and misunderstandings on both sides - that is, of teachers, and of pupils and their families - may jeopardise the goals and aims of education.

In this paper I have chosen to examine these issues by focusing mostly upon the State, law and education officials. This is definitely not to belittle or ignore the importance of finding out more about how Muslim girls and women themselves experience the negotiations they may need to engage in with their teachers and school authorities regarding their choice of clothes, including in sporting contexts. The next step of taking this research forward will involve finding out what kinds of differences there are between how teachers see veiling matters in relation to sports participation, and how the students experience them. This is important work for the future.

\section{References}

Aaltonen, M., Joronen, M. and Villa, S. (2009). Syrjintä Suomessa 2008. Helsinki: Finnish League for Human Rights.

Abaza, M. (2007). Shifting Landscapes of Fashion in Contemporary Egypt. Fashion Theory 11(2/3), pp.281-98.

Ahmad, A. (2011). British football: where are the Muslim female footballers? Exploring the connections between gender, ethnicity and Islam. Soccer \& Society, 12(3), pp.443 - 56.

Ahmed, L. (2011). A Quiet Revolution: The Veil's Resurgence, from the Middle East to America. London: Yale University Press.

\footnotetext{
${ }^{13}$ While laws can be changed with a simple majority in the Parliament, changes to the Constitution require a 2/3 majority to pass.
} 
Al Jazeera (2016). French court overturns "illegal" burkini ban in Nice. www. aljazeera.com/news/2016/09/french-court-overturns-illegal-burkini-bannice160901202423711.html, accessed 8 March 2017.

Allen, C. and Nielsen, J.S. (2002). Summary Report on Islamophobia in the EU after 11 September 2001. European Monitoring Centre on Racism and Xenophobia.

Almila, A. (2017). Introduction: The Veil across the Globe in Politics, Everyday Life, and Fashion. In: A. Almila and D. Inglis (eds), The Routledge International Handbook to Veils and Veiling Practices, London: Routledge.

Almila, A. (2018). Veiling in Fashion: Space and the Hijab in Minority Communities. London: I.B. Tauris.

Almila, A. (2019). Islamic Veiling Meets Fashion - Struggles and Translations. In: S. Brunn and R. Kehrein (eds), Handbook of the Changing World Language Map, Basel: Springer.

Almila, A. (2020). A tale of two centuries: The körtti movement and dress in battles over Finnish politics and identities. Clothing Cultures 6(2), pp.145-62.

Amara, M. (2012). Veiled Women Athletes in the 2008 Beijing Olympics: Media Accounts. The International Journal of the History of Sport 29(4) pp.638 - 51.

Australian Leisure Management (2012). Tribunal allows anti-discrimination exemption for CRACE women-only swimming sessions. www.ausleisure. com.au/news/tribunal-allows-antidiscrimination-exemption-for-c-race-womenonly-swimmin/, accessed 8 March 2017.

Ayub, A. (2011). A Closer Look at FIFA's Hijab Ban: What it Means for Muslim Players and Lessons Learned. SAIS Review 31(1) pp.43-50.

Bartlett, J., Birdwell, J. and Littler, M. (2011). The New Face of Digital Populism. London: Demos.

Benn, T., Pfister, G. and Jawad, H. (2011). Introduction: Muslim Women and Sport. In: T. Benn, G. Pfister, H. Jawad and R. Bailey (eds), Muslim Women and Sport, London: Routledge, pp.1-10.

Borg, S. (2012). Perussuomalaiset. In: S. Borg (ed.), Muutosvaalit 2011, Helsinki: Ministry of Justice, pp.191-210.

Bourdieu, P. (1987). The Force of Law: Toward a Sociology of the Juridical Field. The Hastings Law Journal 38, pp.814-53.

Bracke, S. and Fadil, N. (2012). Is the Headscarf Oppressive or Emancipatory? Field Notes from the Multicultural Debate. Religion and Gender 2(1), pp.36-56.

Brems, E. (2014). Introduction to the Volume. In: E. Brems (ed), The Experiences of Face Veil Wearers in Europe and the Law, Cambridge: Cambridge University Press, pp.1-16.

Dabbagh, O. (2017). Switzerland's legal win against Muslim parents who refused to let their daughters join mixed-sex swimming lessons has drawn Australian parallels. SBS News. $12^{\text {th }}$ January. https://www.sbs.com.au/news/swiss-ruling-on-swimming-segregation-drawsaustralian-parallels, accessed $10^{\text {th }}$ February 2020. 
Dagkas, S. and Benn, T. (2006). Young Muslim Women's Experiences of Islam and Physical Education in Greece and Britain: A Comparative Study. Sport, Education and Society 11(1), pp.21-38.

Dagkas, S., Koshkie Jahromi, M. and Talbot, M. (2011). Reaffirming the values of physical education, physical activity and sport in the lives of young Muslim women. In: T. Benn, G. Pfister, H. Jawad and R. Bailey (eds) Muslim Women and Sport, London: Routledge, pp.1322.

Duits, L. and van Zoonen, L. (2006). Headscarves and Porno-Chic: Disciplining Girls' Bodies in the European Multicultural Society. European Journal of Women's Studies 13(2), pp.103-17.

EACEA Education, Audiovisual and Culture Executive Agency/European Commission (2013). Physical Education and Sport at School in Europe. Eurydice Report. Luxembourg: Publications Office of the European Union.

El-Guindi, F. (1999). Veil: Modesty, Privacy and Resistance. Oxford: Berg.

EOAK (2079/2002). Musliminaisten huivinkäyttö passivalokuvissa. Parliamentary Ombudsperson.

EOAK (1455/2007). Omien vaatteiden käytön kielto vankilassa. Parliamentary Ombudsperson.

EOAM (208/2008). Maahanmuuttajanaisille voidaan varata oma uimahallivuoro. Parliamentary Ombudsperson.

Fagerlund, E. and Maijala, H-M. (2011). Saa hengaa eri porukan kanssa:

Maahanmuuttajataustaisten lasten ja nuorten liikuntaan osallistumisen tukeminen. Liikunnan ja kansanterveyden julkaisuja.

Fitzpatrick, S. (2009). Covering Muslim Women at the Beach: Media Representations of the Burkini. Thinking Gender Papers, UCLA Center for the Study of Women, UC Los Angeles.

Fornerod, A. (2017). Wearing a veil in the French context of laïcité. In: A. Almila and D. Inglis (eds), The Routledge International Handbook to Veils and Veiling Practices, London: Routledge, pp.53-63.

Forsberg, T. (2015). Tutkimus: Suomessa muslimien määrä lähes viisinkertaistuu. Yleisradio, $7^{\text {th }}$ April. https://yle.fi/uutiset/3-7909301, accessed $10^{\text {th }}$ February 2020.

Gökarıksel, B. and Secor, A. (2010). Between Fashion and Tesettür: Marketing and Consuming Women's Islamic Dress. Journal of Middle East Women's Studies 6(3), pp.11848.

Gökarıksel, B. and Secor, A. (2013). Transnational Networks of Veiling-Fashion between Turkey and Western Europe. In: E. Tarlo and A. Moors (eds), Islamic Fashion and AntiFashion, London: Bloomsbury, pp.157-67. 
Haavisto, I. and Kiljunen, P. (2011). Maailman paras maa: EVAn kansallinen arvo- ja asennetutkimus 2011. Taloustieto Oy, www.eva.fi/wp-content/uploads/2011/03/Maailmanparas-maa.pdf.

HE (81/2004). Hallituksen esitys Eduskunnalle laiksi rikoslain 17 luvun, kokoontumislain ja järjestyksenvalvojista annetun lain $8 \S: n$ muuttamisesta. Finnish Government, www.edilex.fi/he/20040081.

Hokkanen, P. (2014). Uskonnonvapaus monikulttuuristuvassa koulussa. Phd thesis. ACTA WASAENSIA 307. University of Vaasa.

Human Rights First (2007). Islamophobia: 2007 Hate Crime Survey. New York: Human Rights First.

Jawad, H., Al-Sinani, Y. and Benn, T. (2011). Islam, Women and Sport. In: T. Benn, G. Pfister, H. Jawad and R. Bailey (eds), Muslim Women and Sport, London: Routledge, pp.2540.

Jokiniemi, E. (2016). Uimahalli kieltää muslimiasut - keskustelu repesi. Länsiväylä. 22 January, www.lansivayla.fi/artikkeli/357759-uimahalli-kieltaa-muslimiasut-keskustelurepesi, accessed 7th February 2016.

Jones, C. (2007). Fashion and Faith in Urban Indonesia. Fashion Theory 11(2/3), pp.211-32. Joseph, S. (2013). Muslim Women in Sports: Participation worldwide. EWIC Staff Report. Kantola, K. (2015). Lännen Media: Suomalaiset yliarvioivat maassa asuvien muslimien määrän. Yleisradio. 2 November, http://yle.fi/uutiset/lannen_media_suomalaiset_yliarvioivat_maassa_asuvien_muslimien_maa ran/8472550, accessed 21st November 2015.

Karlsson Minganti, P. (2013). Burqinis, Bikinis and Bodies: Encounters in Public Pools in Italy and Sweden. In: E. Tarlo and A. Moors (eds), Islamic Fashion and Anti-Fashion, London: Bloomsbury, pp.33-54.

Kelly, M. (2010). Clothes, Culture, and Context: Female Dress in Kuwait. Fashion Theory 14(2), pp.215-36.

Keskinen, S. (2009). Pelkkiä ongelmia? Maahanmuutto poliittisen keskustelun kohteena. In: S. Keskinen, A. Rastas and S. Tuori (eds), En ole rasisti, mutta . . Maahanmuutosta, monikulttuurisuudesta ja kritiikistä, Tampere: Vastapaino.

Keskinen, S., Rastas, A. and Tuori, S. (2009). Johdanto: Suomalainen maahanmuuttokeskustelu tienhaarassa. In: S. Keskinen, A. Rastas and S. Tuori (eds), En ole rasisti, mutta . . Maahanmuutosta, monikulttuurisuudesta ja kritiikistä, Tampere:

Vastapaino.

Kestilä, E. (2006). Is There Demand for Radical Right Populism in the Finnish Electorate?. Scandinavian Political Studies 39(3), pp.169-91.

Khamis, S. (2010). Braving the Burqini ${ }^{\mathrm{TM}}$ : re-branding the Australian beach. Cultural Geographies 17(3), pp.379-90. 
Kılıç, S., Saharso, S. and Sauer, B. (2008). Introduction: The Veil: Debating Citizenship, Gender and Religious Diversity. Social Politics 15(4), pp.397-410.

KK 37/2004 vp Kirjallinen Kysymys. P. Räsänen.

https://www.eduskunta.fi/FI/Vaski/sivut/trip.aspx?triptype=ValtiopaivaAsiakirjat\&docid=kk $+37 / 2004$

Lähdesmäki, T. and Saresma, T. (2014). Reframing Gender Equality in Finnish Online Discussion on Immigration: Populist Articulations of Religious Minorities and Marginalized Sexualities. Nordic Journal of Feminist and Gender Research 22(4), pp.299-313.

LaVM (8/2004) vp, Versio 2.0 Hallituksen esitys laiksi rikoslain 17 luvun, kokoontumislain ja järjestyksenvalvojista annetun lain $8 \$: n$ muuttamisesta. Finnish Government, www.edilex.fi/virallistieto/mt/lavm20040008.

Lenneis, V. and Agergaard, S. (2018). Enacting and resisting the politics of belonging through leisure. The debate about gender segregated swimming sessions targeting Muslim women in Denmark. Leisure Studies 37(6), pp.706-20.

Lewis, R. (2013). Hijab on the Shop Floor: Muslims in Fashion Retail in Britain. In: E. Tarlo and A. Moors (eds), Islamic Fashion and Anti-Fashion. London: Bloomsbury, pp.181-200.

MacLeod, A.E. (1987). Accommodating Protest: Working Women, the New Veiling and Change in Cairo. New York: Columbia University Press.

MacLeod, A.E. (1992). Hegemonic Relations and Gender Resistance: The New Veiling as Accommodating Protest in Cairo. Signs 17(3), pp.533-57.

Martikainen, T. (2008). Muslimit suomalaisessa yhteiskunnassa. In: T. Martikainen, T.

Sakaranaho and M. Juntunen (eds), Islam Suomessa: Muslimit arjessa, mediassa ja yhteiskunnassa, Helsinki: Suomalaisen kirjallisuuden seura.

Mattson, B. (2010). Huivin käyttö kouluissa. Proposal to the Education and Culture Board of Raasepori. 18 May, http://kuntatoimisto.ekenas.fi.

McCrone, K.E. (1988). Playing the Game: Sport and the Physical Emancipation of English Women 1870-1914. Lexington, KY: University Press of Kentucky.

McGoldrick, D. (2006). Human Rights and Religion: The Islamic Headscarf Debate in Europe. Oxford: Hart.

Melton, M. (2016). Brooklyn Pool's Women-only Hours Generate Controversy. www.voanews.com/a/brooklyn-pool-women-only-hoursgenerate-controversy/3366938.html, accessed 8 March 2017.

Moors, A. and Tarlo, E. (2007). Introduction. Fashion Theory 11(2/3), pp.133-42.

MTV (2020). Hampurin opetusviranomaiset yrittivät estää tytöltä hunnun käytön - ei olisi saanut. MTV uutiset, $3^{\text {rd }}$ February. https://www.mtvuutiset.fi/artikkeli/hampurinopetusviranomaiset-yrittivat-estaa-tytolta-hunnun-kayton-ei-olisisaanut/7712880?fbclid=IwAR3V6WGFguUyBGkgO18uK8I9p8AaBDnp8t1GE8ax5kL6f aGcUrSHPhotHyE\#gs.wjnie8, accessed $10^{\text {th }}$ February 2020. 
Opetushallitus. (2014). Perusopetuksen opetussuunnitelman perusteet 2014. Määräykset ja ohjeet 2014:96. Helsinki: Opetushallitus.

Paavola, R. (2016). Maahanmuuttajien pyöräilykurssille osallistunut Nora Kodi: Pyöräilen joka päivä. Yleisradio, $14^{\text {th }}$ May. https://yle.fi/uutiset/3-8879361, accessed $8^{\text {th }}$ September 2019.

Pfister, G. (2000). Doing Sport in a Headscarf? German Sport and Turkish Females. Journal of Sport History 27(3), pp.497-524.

Pfister, G. (2011). Muslim women and sport in diasporas: Theories, discourses and practices - analysing the case of Denmark. In: T. Benn, G. Pfister, H. Jawad and R. Bailey (eds), Muslim Women and Sport, London: Routledge, pp.41-76.

Phillips, A. (2005). Dilemmas of Gender and Culture: The Judge, the Democrat and the Political Activist. In: A. Eisenberg and J. Spinner-Halev (eds), Minorities within Minorities: Equality, Rights and Diversity, Cambridge: Cambridge University Press, pp.113-34.

Puuronen, V. (2011). Rasistinen Suomi. Helsinki: Gaudeamus.

Raittila, P. (2009). Journalismin maahanmuuttokeskustelu: hymistelyä, kriittisyyttä vai rasismin tukemista?. In: S. Keskinen, A. Rastas and S. Tuori (eds), En ole rasisti, mutta . . . Maahanmuutosta, monikulttuurisuudesta ja kritiikista, Tampere: Vastapaino.

Rastas, A. (2009). Rasismin kiistäminen suomalaisessa maahanmuuttokeskustelussa. In: S. Keskinen, A. Rastas and S. Tuori (eds), En ole rasisti, mutta . . Maahanmuutosta, monikulttuurisuudesta ja kritiikistä, Tampere: Vastapaino.

Rottmann, S.B. and Marx Ferree, M. (2008). Citizenship and Intersectionality: German Feminist Debates about Headscarf and Antidiscrimination Laws. Social Politics 15(4), pp.481-513.

Roy, O. (2004). Globalized Islam: The Search for a New Ummah. New York: Columbia University Press.

Savolainen, L. (2016). "Uimahallit ovat jämähtäneet 1970-luvulle” - Video: tällainen on kiistelty muslimien uikkari. Yleisradio. 18 January, http://yle.fi/uutiset/uimahallit_ovat_jamahtaneet_1970luvulle_video_tallainen_on_kiistelty_muslimien_uikkari/8599247, accessed 7th February 2016.

Shavit, U. and Wiesenbach, F. (2012). An "Integrating Enclave": The Case of Al-Hayat, Germany's First Islamic Fitness Center for Women in Cologne. Journal of Muslim Minority Affairs 32(1), pp.47-61.

Stadt Alfeld (310/XVII). Berge Bad-Badebekleidung. Der Burgermeister.

Tillaeus, J. (2019). "Naiset tulevat altaaseen meikit kasvoilla ja 3 pulloa lakkaa päässä" hengenpelastajan mukaan uimahallien säännöt keskittyvät vääriin asioihin. Yleisradio, $28^{\text {th }}$ August. https://yle.fi/uutiset/3-10940088, accessed 29 ${ }^{\text {th }}$ August 2019. 
Toffoletti, K. and Palmer, C. (2017). New approaches for studies of Muslim women and sport. International Review for the Sociology of Sport 52(2), pp.146-63.

Tuori, S. (2012). Monikulttuurisuus ja sukupuolten välinen tasa-arvo. In: J. Kantola, K. Nousiainen and M. Saari (eds), Tasa-arvo toisin nähtynä: Oikeuden ja politiikan näkökulmia tasa-arvoon ja yhdenvertaisuuteen, Helsinki: Gaudeamus.

Turner, B.S. (2008). The Body \& Society. Third Edition. London: Sage.

Vakulenko, A. (2012). Islamic Veiling in Legal Discourse. Oxon: Routledge.

Vastamäki, J. (2004). Maahanmuuttajan liikuntatunti - liikunnanopettajien kokemuksia.

Unpublished MA thesis. Jyväskylä University.

Venice Commission (2008). Opinion on the Constitution of Finland. Opinion No. 420/2007. Venice: European Commission for Democracy through Law.

Walseth, K. and Fasting, K. (2003). Islam's view on physical activity and sport: Egyptian women interpreting Islam. International review for the sociology of sport 38(1), pp.45-60.

Walseth, K. and Strandbu, Å. (2014). Young Norwegian-Pakistani women and sport: How does culture and religiosity matter?. European Physical Education Review 20(4), pp.489507.

Westerfield, J.M. (2006). Behind the Veil: An American Legal Perspective on the European Headscarf Debate. The American Journal of Comparative Law 54(3), pp.637-78. 